\title{
SIGNIFICANCE OF PARTIAL ROOT ZONE DRYING AND MULCHES FOR WATER SAVING AND WEED SUPPRESSION IN WHEAT
}

\author{
S. Ahmad ${ }^{1,5}$, M. A. S. Raza ${ }^{1}$, M. F. Saleem ${ }^{2, *}$, R. Iqbal ${ }^{1}$, M. S. Zaheer ${ }^{1}$, I. Haider ${ }^{1}$, M. U. Aslam ${ }^{1}$, M. Ali $^{3}$ and I. H. Khan ${ }^{4}$ \\ ${ }^{1}$ University College of Agriculture \& Environmental Sciences, Department of Agronomy, The Islamia University of \\ Bahawalpur, Bahawalpur, Pakistan; ${ }^{2}$ Department of Agronomy, University of Agriculture Faisalabad, Pakistan \\ ${ }^{3}$ University College of Agriculture \& Environmental Sciences, Department of Soil Science, The Islamia University of \\ Bahawalpur, Bahawalpur, Pakistan; ${ }^{4}$ Department of Agronomy, Nanjing Agricultural University, China \\ ${ }^{5}$ Agriculture (Extension) Department Punjab, Markaz Chounawala, Bahawalpur, Pakistan \\ *Corresponding author's e-mail:mfsuaf@yahoo.com
} Published online January 02, 2020

\begin{abstract}
One of the main negative effects of climate change is the increasing scarcity of water worldwide. Wheat is the second major staple food of the world and drought is the main factor affecting its production. In order to ensure food security, there is need to adopt easy and economic techniques for increasing crop production under limited water resources. Two of the effective techniques are; use of ground covers and partial root zone drying (PRD). Experiments were comprised of two irrigation methods $\left(\mathrm{I}_{1}=\right.$ irrigation on both sides of roots and $\mathrm{I}_{2}=$ irrigation to only one side of root as alternate irrigation) and four ground covers $\left(\mathrm{M}_{0}=\right.$ open ground without any cover, $\mathrm{M}_{1}=$ black plastic cover, $\mathrm{M}_{2}=$ wheat straw cover and $\mathrm{M}_{4}=$ cotton sticks cover). Results revealed that more spike length, number of spikelets and grains were found in full irrigation treatment. While water use efficiency and grain nutrient (NPK) contents were more in PRD. All soil covers suppress the weeds and significantly influenced the yield attributes as well as the grain nutrient contents. However, black plastic cover performed the best. It was concluded that joint use of both techniques was more effective than their sole application and combination of PRD with black plastic mulch performed the best than rest of the treatments.
\end{abstract}

Keywords: Ground covers, Partial root zone drying, grain yield, Quality traits, WUE, Weed control efficiency.

\section{INTRODUCTION}

The world population is expected to reach about 9.2 billion by 2050 . So, there is dire need to increase the global food production up to $40 \%$ in order to ensure food security (Tilman et al., 2011). Furthermore, various biotic and abiotic constraints adversely affect the crop production resulting $30 \%$ to $60 \%$ yield loss annually (Tester and Langridge, 2010).

Drought is a multi-destructive stress and is considered as one of the most important factors limiting wheat yield around the world. Wheat production under changing climate has been an arduous task (Shahid et al., 2017). As climate change leads to increasingly hotter and drier summers, the effects of drought constraints on yield and yield components have increased especially when faced at critical growth stages (Manikavelu et al., 2011).

Among the various crop yield limiting factors, weed control has always been a main problem. Despite many advances in weed management technology, crop growers still face significant yield losses due to weeds (Harker and O'donovan, 2013). Weeds reduce the yield by utilizing the sun light, water, space and fertilizer. It has been estimated that weeds cause $23 \%$ wheat yield reduction worldwide (Gaba et al., 2016). Less plant height, number of tillers per plant, number of grains per spike, 1000 grains weight and grain yield was recorded in weed infested wheat as compared to the control treatment (Hussain et al., 2017).

About $80 \%$ of the world's allocated water resource is currently consumed by irrigated agriculture. This level of consumption by agriculture is not sustainable in future due to more demand and less availability. At present and more so in the future, Irrigation management will shift from emphasizing production per unit area towards maximizing the production per unit of water consumed (Fereres and Garcia-Vila, 2019).

Thus, there is dire need to develop techniques which not only reduce water loss but also give appreciable yield under limited water availability. Many ways like breeding (Mwadzingen et al., 2016), use of compatible solutes (Blum, 2017) and growth regulators (Dwivedi et al., 2017) have been used for drought mitigation but these are time consuming and costly so mostly adopted in high value crops (fruits, ornamentals). Secondly most of the farmers of arid to semi-arid regions are small land holders with limited resources. So, 
development of economic and easily adopted technique is necessary to tackle this problem.

Soil covers (mulches) conserve moisture because water that evaporates from the soil under the film condenses on the lower surface of the film and falls back to the soil as droplets. The opaque mulches do not allow the sun light to pass through and hence weeds growth is completely arrested (Game et al., 2017). Ijaz and Ali (2007) recorded more nutrient uptake and wheat yield under mulch as compared to control (un-mulched) treatment. Selection and usage of suitable mulches is one of good way for conserving soil moisture and sustainable crop production which should be investigated more and more in order to determine the short term and long term effects of mulches on cultivated lands (Bandopadhyay et al., 2018).

Partial root zone drying (PRD) is a technique in which water is applied to plants in a manner that half portion of the roots become wet and other half remains dry in a cyclic way. PRD conserves soil moisture and increase crop water use efficiency without marked yield loss. PRD induced production of abscisic acid (ABA) by plant roots minimize stomatal conductance, minimize transpirational water loss and make plant more water efficient. Hence increase water use efficiency (Raza et al., 2017). It was first used by Grimes et al. (1968) in cotton and reported $32 \%$ water saving with $5 \%$ yield loss. Now this technique is successfully used in many crops like tomato (Kirda et al., 2004), grapes (DeLaHera et al., 2007), potato (Shahnazari et al., 2007) and citrus (Hutton and Loveys, 2011) with promising results.

Although PRD minimizes the water loss in the form of transpiration but evaporation from soil surface is also a major reason of water wastage. So, in present study PRD is coupled with mulching in order to minimize the water loss in both forms transpiration and transpiration, conservation more moisture in soil in-order to further increase the efficiency of PRD. The study will help the farmers (especially in arid and semi-arid areas) to get better wheat yield with less water availability by using economic and easily adoptive techniques.

\section{MATERIALS AND METHODS}

Field experiments were conducted at research area of department of Agronomy, The Islamia University of Bahawalpur (Latitude: 29 23'60.00"N, Longitude: 71 40'59.99"E) during 2016-17 and 2017-18. Experimental site is characterized with semi-arid climate with mean maximum and minimum research duration temperature of 27.46 and 12.63 respectively, with average rainfall of $2.5 \mathrm{~mm}$. Wheat variety galaxy 2013 was used in the experiments. Seeds were purchased from Ayub Agriculture Research Institute Faisalabad and surface sterilized before sowing. Experimental soil was of sandy loam type with $\mathrm{pH}=7.8$ and $7.9, \mathrm{~N}=160 \mathrm{ppm}$ and159 ppm; $\mathrm{P}=5 \mathrm{ppm}$ and $5.4 \mathrm{ppm} ; \mathrm{K}=100 \mathrm{ppm}$ and $112 \mathrm{ppm} ; \mathrm{OM}=0.53$ and $0.52 \%$; permanent wilting point $=0.041$ and $0.042 \mathrm{~m}^{3} \mathrm{~m}^{-3}$; Electric conductivity $=2.52$ and $2.51 \mu \mathrm{scm}^{-1}$ during 2016-17 and 2017-18, respectively. Sowing was done on $11^{\text {th }}$ November during both the years of study. Seeds@100 kg per hectare were sown on manually prepared beds having $9 \mathrm{~cm}$ apart rows by using hand drill. Whole dose of fertilizer was applied at sowing.

Experiment was laid out in RCBD with split plot arrangement. Two factors were studied in the experiment. Irrigation methods $\left(\mathrm{I}_{1}=\right.$ control and $\left.\mathrm{I}_{2}=\mathrm{PRD}\right)$ were kept in main plots and different soil covers were kept in sub plots $\left(\mathrm{M}_{1}=\right.$ un-mulched, $\mathrm{M}_{2}=$ black plastic mulch, $\mathrm{M}_{3}=$ wheat straw mulch and $\mathrm{M}_{4}=$ cotton sticks mulch). After complete emergence of wheat, mulches were applied between the rows manually. Water @ 19 acre inches and 10 acre inches, was applied in control (both sides of plants) and PRD (one side of plants) treatments, respectively.

Growth and yield parameters were recorded as per standard protocols. Number of tillers and number of weeds were counted when crop reached at maturity. Harvest index (HI) was calculated by using the following formula:

$\mathrm{HI}=\frac{\text { Grain yield }}{\text { Biological yield }} \times 100$

Water use efficiency (WUE) was calculated by adopting the formula followed by Hussain and Al-Jaloud (1995)

Water use efficiency $($ WUE $)=$ GY $/$ TWA

Where $\mathrm{GY}=$ Grain yield $\left(\mathrm{kg} \mathrm{ha}^{-1}\right)$

TWA $=$ Total water applied $(\mathrm{mm})$

Nitrogen, phosphorus and potassium contents in wheat grain were measured by adopting the procedures followed by Battaglia et al. (1983). Crop was harvested on $23^{\text {rd }}$ April during both the years of research.

Statistical analysis: STATISTIX (version 8.1) program with linear model technique was used for statistical analysis of recorded data. Analysis of variance (ANOVA) technique was used to find the significance. To compare the treatments' means, least significant difference (LSD) test was applied at 5\% probability level (Steel et al., 1997).

\section{RESULTS}

Plant height is an important indicator of crop growth and yield. With more height, more will be the number of nodes and number of leaves on plant and ultimately more photosynthesis. Significantly different plant heights were attained under different irrigation regimes and mulch treatments (Table1). For water regimes more plant height was observed in normal irrigation treatment $\left(\mathrm{I}_{1}\right)$ and less plant height was 
recorded in PRD treatment $\left(\mathrm{I}_{2}\right)$. Reduced height in PRD treated plants than control treatment might be due to less cell turgidity and hence less mitosis. For mulches maximum plant height was found under black plastic mulch $\left(\mathrm{M}_{1}\right)$ followed by in wheat straw mulch $\left(\mathrm{M}_{2}\right)$, cotton stick mulch $\left(\mathrm{M}_{3}\right)$ and minimum plant height was found in un-mulched treatment $\left(\mathrm{M}_{0}\right)$. Mulches conserve soil moisture and make it available to the plants which improve cell turgidity, cell division and plant height as compared to un-mulched plants. Similar results were reported by Ahmad et al. (2015). However interaction of studied factors influenced non significantly on plant height of wheat.

Number of tillers is an important contributor towards final yield. Water regimes had significant influence on number of fertile tillers of wheat (Table1) with maximum number of tillers in normal irrigated plants $\left(\mathrm{I}_{1}\right)$ and minimum number of tillers in PRD treated plants $\left(I_{2}\right)$ due to water availability to half plant roots under PRD. Mulches did not significantly affect the number of fertile tillers of wheat. Similarly interactive effect of mulches and irrigation regimes had nonsignificant influence on number of fertile tillers.

Significant variation in spike length was recorded with irrigation regimes (Table1). More lengthy spikes were found under control condition $\left(\mathrm{I}_{1}\right)$ and less $\mathrm{S}$ pike length was recorded in PRD treatment $\left(I_{2}\right)$. However, soil covers did not significantly influence the spike length of wheat. Similarly interactive effect of both factors was also non-significant on spike length of wheat during both the years of study.

Significant effects of irrigation regimes were observed on number of spikelets per spike of wheat in 2017-18 and non significant effects in 2016-17 with maximum values in $\left(\mathrm{I}_{0}\right)$ and minimum values in PRD treatment $\left(\mathrm{I}_{1}\right)$. While soil covers and their interaction with irrigation regimes had non significant effect on number of spikelets per spike during both the years of study.

Irrigation regimes had non significant effect on 1000 grain weight of wheat, indicating that PRD has favorable effects on 1000 grain weight which is the major component contributing towards final yield. Similarly different mulch materials and their interaction with irrigation regimes also gave non-significant results on 1000 grain weight for both the years of study.

Data given in table 2 exhibit significant effect of irrigation regimes on biological yield of wheat in 2016-17 and non-significant effects in 2017-18. More biological yield was found with normal irrigation treatment $\left(\mathrm{I}_{1}\right)$ than with PRD treatment $\left(\mathrm{I}_{2}\right)$. While mulches significantly affected the biological yield of wheat during both years. Maximum biological yield was found under black plastic mulch $\left(\mathrm{M}_{1}\right)$ followed by in wheat straw mulch $\left(\mathrm{M}_{2}\right)$, cotton stick mulch $\left(\mathrm{M}_{3}\right)$ and minimum biological yield was found in un-mulched treatment $\left(\mathrm{M}_{0}\right)$. Interaction of studied factors had significant influence on biological yield in 2016-17and non significant influence in 2017-18 indicating that combined use of mulches and irrigation regimes improve the overall plant growth under both normal and deficit water conditions.

Spike length, number of spikelets, number of grains per spike and 1000 grain weight (yield attributes) directly affect the grain yield. PRD treated wheat plants produced smaller spikes as compared to the control irrigated plants (Taheri et al., 2011). Less turgor pressure under PRD is main reason for this as it leads towards less cell division and less growth (Farooq et al., 2009). Less number of spikelets per spike under water deficit conditions is mainly due to less spikelets primordial formation during tillering stage or may be due to death of floret at the terminal and basal ends of the spike (Maqbool et al., 2015). Under less water availability, number of grains decreased mainly due to the dehydration of pollen grain (Kumari, 2012). However, 1000 grain weight was not significantly affected by irrigation techniques, it indicates that although PRD reduces the vegetative growth but transfers the assimilates towards economic part (grain) as like in normal irrigation treatment. Partial drought at post anthesis stage in wheat (grain filling) increased the transfer rate of assimilates towards $\mathrm{g}$ rain as compared to other plant parts. Similar to results of present study, Saeed et al. (2008) reported reduction in vegetative growth under PRD but less in assimilates translocation towards economic parts and final yield.

The ultimate goal of crop production is to achieve maximum grain yield with available resources. Grain yield was found to be influenced significantly by both factors irrigation regime and mulches (Table 2). For water regimes maximum yield was recorded in normal irrigation treatment $\left(\mathrm{I}_{1}\right)$ and less in PRD treatment $\left(\mathrm{I}_{2}\right)$. Less grain yield in PRD treatment might have been due to less number of tillers as compared to control irrigation treatment. Among the mulches highest grain yield was obtained under black plastic mulch $\left(\mathrm{M}_{1}\right)$ followed by in wheat straw mulch $\left(\mathrm{M}_{2}\right)$ which was at par with cotton stick mulch $\left(\mathrm{M}_{3}\right)$ and minimum grain yield was found under un-mulched condition $\left(\mathrm{M}_{0}\right)$. On the same lines Ramakrishna et al. (2006) recorded higher yield under mulch conditions as compared to un-mulched conditions. Interaction of mulches and irrigation regimes also significantly influenced the grain yield of wheat with maximum grain yield was found in $\mathrm{M}_{1} \mathrm{I}_{1}$ and minimum grain yield was recorded in $\mathrm{M}_{0} \mathrm{I}_{2}$ for both years. Combined use of mulches and irrigation is more effective than their sole application as in combined application mulches decrease transpirational water loss and PRD reduces evaporational water loss (Ahmad et al., 2015).

Different irrigation regimes and mulches influenced significantly the water use efficiency (WUE) of wheat. For water regimes maximum WUE was recorded in PRD treatment $\left(\mathrm{I}_{2}\right)$ and minimum was found 
in normal irrigation treatment $\left(\mathrm{I}_{1}\right)$. It is due to less amount of applied water, less leaf area (less transpiration) and less weed infestation as in PRD as compared to normal irrigation treatment. Similar results were reported by Kusakabe et al. (2016). Among the mulches maximum WUE was recorded under black plastic mulch $\left(\mathrm{M}_{1}\right)$ followed by in wheat straw mulch $\left(\mathrm{M}_{2}\right)$ which was at par with cotton stick mulch $\left(\mathrm{M}_{3}\right)$ and minimum (2.14) was found in $\mathrm{M}_{0}$. More WUE of wheat under mulch treatment was probably due to more water conservation and less evaporational water loss which made water available to the plants (Ahmad et al., 2015). Interaction of soil covers and irrigation regimes also significantly influenced the water use efficiency of wheat with maximum WUE was recorded in $M_{1} I_{1}$ and minimum WUE was recorded in $\mathrm{M}_{0} \mathrm{I}_{1}$. Similar trend was observed in second year of study.

Different mulches influenced significantly the grain nitrogen contents of wheat. Maximum grain nitrogen contents were recorded under black plastic mulch $\left(\mathrm{M}_{1}\right)$ followed by wheat straw mulch $\left(\mathrm{M}_{2}\right)$ which was at par with cotton stick mulch $\left(\mathrm{M}_{3}\right)$ and minimum value was recorded in un-mulched treatment. Ground covers increase the nitrogen uptake by plant due to better moisture availability and more mass flow under mulches than un-mulched treatment (Maurya et al., 2017). While irrigation regimes did not significantly affect the grain nitrogen contents. An abrupt increase in soil water potential after re-watering of dry soil portion not only enhances the breakdown of microbial dead matter but also increases the nitrogen mineralization (Mummey et al., 1994). That's why nitrogen was non-significantly affected by PRD and control Irrigation. Similarly, interaction of mulches with irrigation regimes also non significantly influenced the grain nitrogen contents of wheat which indicates that both factors (mulches and water regimes) interacted synergistically and improved the nitrogen uptake by wheat. Same trend was observed in second year of study.

Different irrigation regimes and mulches influenced significantly the grain phosphorus contents of wheat. For water regimes maximum grain phosphorus contents were recorded in control treatment $\left(\mathrm{I}_{1}\right)$ and minimum were found in PRD irrigation treatment $\left(\mathrm{I}_{2}\right)$. Among the mulches maximum grain phosphorus contents were under black plastic mulch $\left(\mathrm{M}_{1}\right)$ followed by in wheat straw mulch $\left(\mathrm{M}_{2}\right)$ which was at par with cotton stick mulch $\left(\mathrm{M}_{3}\right)$ and minimum grain phosphorus contents were found in $\mathrm{M}_{0}$. Phosphorus uptake was increased under mulches due to higher soil moisture contents, more diffusion and less down ward movement of $\mathrm{P}$ (Othieno, 1973). However, interaction of mulches and irrigation regimes did not significantly influence the grain phosphorus contents of wheat indicating that both factors (mulches and water regimes) interact synergistically and improve the phosphorus availability to wheat. Similar trend was observed in second year of study.

Potassium is essential for osmotic adjustment and turgor maintenance of plants especially under water deficit conditions (Hassan et al., 2017). Different irrigation regimes and mulches influenced significantly the grain potassium contents of wheat. For water regimes maximum grain potassium contents were recorded in PRD treatment $\left(\mathrm{I}_{2}\right)$ and minimum were found in normal irrigation treatment $\left(\mathrm{I}_{1}\right)$. Among the mulches maximum grain potassium contents were under black plastic mulch $\left(\mathrm{M}_{1}\right)$ followed by in wheat straw mulch $\left(\mathrm{M}_{2}\right)$ which was at par with cotton stick mulch $\left(\mathrm{M}_{3}\right)$ and minimum grain potassium contents were found under un-mulched conditions $\left(\mathrm{M}_{0}\right)$. More $\mathrm{P}$ uptake under mulches is due to more moisture availability and root growth which increase the uptake of relatively immobile nutrients like $\mathrm{P}$ and K (Merwe and Prins, 2012). Similar results were also reported by Sekhon et al. (2008). However, interaction of mulches and irrigation regimes did not significantly influence the grain potassium contents of wheat.

Significant effects of both factors irrigation regimes and mulches were observed on weed infestation of wheat during both the years of study. Among the mulches minimum number of weeds and weed biomass were recorded under black plastic mulch $\left(\mathrm{M}_{1}\right)$ followed by wheat straw mulch $\left(\mathrm{M}_{2}\right)$, cotton sticks mulch $\left(\mathrm{M}_{3}\right)$ and highest values were found under un-mulched condition $\left(\mathrm{M}_{0}\right)$. Ground covers suppress the weed growth by reducing light availability and physical barrier for weed emergence and further growth. However black plastic mulch performed best than other mulches due to more uniformity in structure (Ahmad et al., 2015). For irrigation regimes maximum number of weeds and weed biomass were recorded in normal irrigation treatment $\left(\mathrm{I}_{1}\right)$ and minimum values were recorded in PRD treatment $\left(\mathrm{I}_{2}\right)$. More weeds infestation under normal irrigation treatment was due to more water availability to soil than PRD treatment which results in more weed seed germination (Nasrullah et al., 2011). All combinations of mulches and irrigation regimes also significantly controlled the weeds with highest weed control was found in $\mathrm{M}_{1} \mathrm{I}_{2}$ and minimum in $\mathrm{M}_{0} \mathrm{I}_{1}$. 
Table.1. Effect of different ground covers and irrigation regimes on plant height, number of tillers, spike length, number of spikelets per spike and number of grains per spike in wheat.

\begin{tabular}{|c|c|c|c|c|c|c|c|c|c|c|}
\hline \multirow{2}{*}{$\begin{array}{l}\text { Ground } \\
\text { covers } \\
\text { Year }\end{array}$} & \multicolumn{2}{|c|}{ Plant height (cm) } & \multicolumn{2}{|c|}{ No. of tillers $\mathrm{m}^{-2}$} & \multicolumn{2}{|c|}{ Spike length $(\mathrm{cm})$} & \multicolumn{2}{|c|}{$\begin{array}{c}\text { No. of spikelets per } \\
\text { spike }\end{array}$} & \multicolumn{2}{|c|}{ No. of grains per spike } \\
\hline & $2016-17$ & $2017-18$ & $2016-17$ & $2017-18$ & $2016-17$ & $2017-18$ & $2016-17$ & $2017-18$ & $2016-17$ & $2017-18$ \\
\hline $\mathrm{M}_{0}$ & $87.67 \mathrm{C}$ & $85.83 \mathrm{C}$ & 374.50 & 368.17 & 11.81 & $11.40 \mathrm{~A}$ & 17.38 & 16.52 & 40.16 & 39.24 \\
\hline $\mathrm{M}_{1}$ & $100.17 \mathrm{~A}$ & $97.83 \mathrm{~A}$ & 387.11 & 377.00 & 13.41 & $12.47 \mathrm{~A}$ & 18.75 & 17.41 & 42.33 & 40.67 \\
\hline $\mathrm{M}_{2}$ & $93.83 \mathrm{~B}$ & $92.50 \mathrm{~B}$ & 380.17 & 372.00 & 12.41 & $11.47 \mathrm{~A}$ & 17.50 & 16.33 & 40.76 & 38.17 \\
\hline $\mathrm{M}_{3}$ & $90.00 \mathrm{C}$ & $88.33 \mathrm{C}$ & 379.50 & 372.50 & 12.33 & $11.47 \mathrm{~A}$ & 17.16 & 15.56 & 39.16 & 39.83 \\
\hline LSD & 3.14 & 3.43 & NS & NS & NS & NS & NS & NS & NS & NS \\
\hline \multicolumn{11}{|c|}{ Irrigation regimes } \\
\hline $\mathrm{I}_{1}$ (Control) & $98.83 \mathrm{~A}$ & $96.83 \mathrm{~A}$ & $403.50 \mathrm{~A}$ & $391.08 \mathrm{~A}$ & $13.51 \mathrm{~A}$ & $12.62 \mathrm{~A}$ & 19.00 & $17.73 \mathrm{~A}$ & 42.00 & $40.87 \mathrm{~A}$ \\
\hline $\mathrm{I}_{2}(\mathrm{PRD})$ & 87.00B & $85.42 \mathrm{~B}$ & $356.67 \mathrm{~B}$ & $351.75 \mathrm{~B}$ & $11.41 \mathrm{~B}$ & $10.78 \mathrm{~B}$ & 16.40 & $15.17 \mathrm{~B}$ & 39.21 & $38.08 \mathrm{~B}$ \\
\hline LSD & 9.82 & 11.12 & 13.78 & 12.20 & 1.81 & 1.13 & NS & 1.93 & NS & 2.55 \\
\hline $\begin{array}{l}\text { Ground co } \\
\text { NS }\end{array}$ & $\times$ Irrigation & & & & & & & & & \\
\hline
\end{tabular}

Means not sharing a common letter differ at $5 \%$ probability level.

Table.2. Effect of different ground covers and irrigation regimes on 1000 grain weight, biological yield, grain yield, harvest index and water use efficiency in wheat.

\begin{tabular}{|c|c|c|c|c|c|c|c|c|c|c|}
\hline \multirow{2}{*}{\begin{tabular}{|l}
$\begin{array}{c}\text { Ground } \\
\text { covers }\end{array}$ \\
Year
\end{tabular}} & \multicolumn{2}{|c|}{$\begin{array}{c}1000 \text { grain weight } \\
\text { (g) }\end{array}$} & \multicolumn{2}{|c|}{$\begin{array}{c}\text { Biological yield } \\
\left(\mathrm{kg} \mathrm{ha}^{-1}\right)\end{array}$} & \multicolumn{2}{|c|}{$\begin{array}{c}\text { Grain yield } \\
\left(\mathrm{kg} \mathrm{ha}^{-1}\right)\end{array}$} & \multicolumn{2}{|c|}{$\begin{array}{c}\text { Harvest Index } \\
(\%)\end{array}$} & \multicolumn{2}{|c|}{$\begin{array}{c}\text { WUE } \\
\left(\mathrm{kg} \mathrm{ha}^{-1} \mathrm{~mm}^{-1}\right)\end{array}$} \\
\hline & $2016-17$ & $2017-18$ & $2016-17$ & $2017-18$ & $2016-17$ & $2017-18$ & $2016-17$ & 2017-18 & 2016-17 & $2017-18$ \\
\hline $\mathrm{M}_{0}$ & 34.92 & 33.75 & 14410B & $13370 \mathrm{C}$ & 5068D & 4890C & 35.55 & 35.63 & $2.20 \mathrm{C}$ & $2.14 \mathrm{D}$ \\
\hline $\mathrm{M}_{1}$ & 36.23 & 36.31 & $15710 \mathrm{~A}$ & $14950 \mathrm{~A}$ & $5455 \mathrm{~A}$ & $5228 \mathrm{~A}$ & 35.31 & 35.31 & $2.40 \mathrm{~A}$ & $2.31 \mathrm{~A}$ \\
\hline $\mathrm{M}_{2}$ & 35.76 & 35.20 & 14920B & 14340B & $5242 B$ & 5089B & 35.79 & 35.48 & $2.31 \mathrm{~B}$ & $2.24 \mathrm{~B}$ \\
\hline $\mathrm{M}_{3}$ & 35.16 & 34.50 & 14400B & $13820 \mathrm{BC}$ & $5157 \mathrm{C}$ & $5012 \mathrm{C}$ & 36.54 & 34.31 & $2.24 \mathrm{C}$ & $2.20 \mathrm{C}$ \\
\hline LSD & NS & NS & 0.35 & 0.58 & 85.75 & 76.99 & NS & NS & 0.042 & $\mathbf{0 . 0 3 7}$ \\
\hline \multicolumn{11}{|l|}{ Irrigation } \\
\hline $\mathrm{I}_{1}$ (Control) & 36.63 & 36.50 & 15.81 & $17.05 \mathrm{~A}$ & $5.41 \mathrm{~A}$ & $5.64 \mathrm{~A}$ & 33.93 & 33.27 & $1.92 \mathrm{~B}$ & $1.86 \mathrm{~B}$ \\
\hline $\mathrm{I}_{2}(\mathrm{PRD})$ & 34.41 & 33.75 & 12.43 & $12.67 \mathrm{~B}$ & 4.69B & 4.81B & 37.36 & 37.06 & $2.76 \mathrm{~A}$ & $2.58 \mathrm{~A}$ \\
\hline LSD & NS & NS & NS & 4.29 & 0.63 & 0.68 & NS & NS & 0.34 & 0.28 \\
\hline $\mathrm{M}_{0} \mathrm{I}_{1}$ & 35.93 & 35.93 & $16.84 b$ & 14.88 & $5.55 b$ & $5.30 \mathrm{~b}$ & 33.82 & 33.05 & $1.96 \mathrm{c}$ & $1.82 \mathrm{e}$ \\
\hline $\mathrm{M}_{0} \mathrm{I}_{2}$ & 37.43 & 31.56 & $11.99 \mathrm{e}$ & 11.85 & $4.58 \mathrm{~d}$ & $4.47 \mathrm{e}$ & 37.27 & 38.20 & $2.65 b$ & $2.46 \mathrm{c}$ \\
\hline $\mathrm{M}_{1} \mathrm{I}_{1}$ & 36.83 & 37.60 & $18.24 \mathrm{a}$ & 16.77 & $6.00 \mathrm{a}$ & $5.70 \mathrm{a}$ & 32.85 & 31.85 & $1.94 \mathrm{c}$ & $1.89 \mathrm{~d}$ \\
\hline $\mathrm{M}_{1} \mathrm{I}_{2}$ & 36.33 & 35.03 & $13.18 \mathrm{~d}$ & 13.13 & $5.10 \mathrm{~b}$ & $4.95 \mathrm{c}$ & 37.76 & 38.76 & $2.85 \mathrm{a}$ & $2.73 a$ \\
\hline $\mathrm{M}_{2} \mathrm{I}_{1}$ & 33.91 & 36.50 & $16.96 \mathrm{~b}$ & 16.10 & $5.76 \mathrm{~b}$ & $5.565 \mathrm{a}$ & 34.12 & 33.53 & $1.92 \mathrm{c}$ & $1.88 \mathrm{~d}$ \\
\hline
\end{tabular}




\begin{tabular}{|c|c|c|c|c|c|c|c|c|c|c|}
\hline $\mathrm{M}_{2} \mathrm{I}_{2}$ & 35.03 & 33.90 & $12.87 \mathrm{~d}$ & 12.58 & $4.82 \mathrm{c}$ & $4.71 \mathrm{~d}$ & 37.47 & 37.44 & $2.7 b$ & $2.60 \mathrm{~b}$ \\
\hline $\mathrm{M}_{3} \mathrm{I}_{1}$ & 34.70 & 36.00 & $16.16 \mathrm{c}$ & 15.48 & $5.56 b$ & $5.40 \mathrm{ab}$ & 35.07 & 34.65 & $1.93 \mathrm{~d}$ & $1.86 \mathrm{de}$ \\
\hline $\mathrm{M}_{3} \mathrm{I}_{2}$ & 34.00 & 33.00 & $12.65 \mathrm{~d}$ & 12.16 & $4.74 c$ & $4.62 \mathrm{~d}$ & 38.01 & 33.85 & $2.7 \mathrm{~b}$ & $2.55 b$ \\
\hline LSD & NS & NS & 0.76 & NS & 0.12 & 0.10 & NS & NS & 0.07 & 0.05 \\
\hline
\end{tabular}

Means not sharing a common letter differ at $5 \%$ probability level.

Table.3. Effect of different ground covers and irrigation regimes on grain nitrogen contents, phosphorus contents, potassium contents, number of weeds and weed biomass in wheat.

\begin{tabular}{|c|c|c|c|c|c|c|c|c|c|c|c|}
\hline \multirow{2}{*}{$\begin{array}{l}\text { Ground } \\
\text { covers } \\
\text { Year }\end{array}$} & \multicolumn{2}{|c|}{ Nitrogen contents } & \multicolumn{3}{|c|}{ Phosphorus contents } & \multicolumn{2}{|c|}{ Potassium contents } & \multicolumn{2}{|c|}{ No. of weeds $\mathrm{m}^{-2}$} & \multicolumn{2}{|c|}{$\begin{array}{c}\text { Weed biomass } \\
\left(\mathrm{g} \mathrm{m}^{-2}\right) \\
\end{array}$} \\
\hline & $2016-17$ & $2017-18$ & $2016-17$ & & $2017-18$ & $2016-17$ & $2017-18$ & $2016-17$ & $2017-18$ & $2016-17$ & $2017-18$ \\
\hline $\mathrm{M}_{0}$ & $0.040 \mathrm{C}$ & $0.044 \mathrm{~B}$ & $3.38 \mathrm{C}$ & & $3.64 \mathrm{C}$ & $7.93 \mathrm{C}$ & $7.97 \mathrm{C}$ & $64.22 \mathrm{~A}$ & $62.16 \mathrm{~A}$ & $134.62 \mathrm{~A}$ & $67.50 \mathrm{~A}$ \\
\hline $\mathrm{M}_{1}$ & $0.049 \mathrm{~A}$ & $0.051 \mathrm{~A}$ & $3.59 \mathrm{~A}$ & & $3.96 \mathrm{~A}$ & $8.1350 \mathrm{~A}$ & $8.20 \mathrm{~A}$ & $17.00 \mathrm{D}$ & $15.66 \mathrm{D}$ & $41.17 \mathrm{D}$ & $21.16 \mathrm{D}$ \\
\hline $\mathrm{M}_{2}$ & $0.043 \mathrm{~B}$ & $0.047 \mathrm{~B}$ & $3.51 \mathrm{~B}$ & & $3.77 \mathrm{~B}$ & 8.04B & $8.16 \mathrm{~A}$ & $29.83 \mathrm{C}$ & $28.33 \mathrm{C}$ & $62.00 \mathrm{C}$ & $37.33 \mathrm{C}$ \\
\hline $\mathrm{M}_{3}$ & $0.041 \mathrm{BC}$ & $0.044 \mathrm{~B}$ & $3.42 \mathrm{BC}$ & & $3.69 \mathrm{~B}$ & $8.01 \mathrm{~B}$ & $8.05 \mathrm{~B}$ & $38.33 \mathrm{~B}$ & $36.33 \mathrm{~B}$ & $76.83 \mathrm{~B}$ & $51.50 \mathrm{~B}$ \\
\hline LSD & 0.002 & 0.003 & 0.12 & & 0.10 & 0.07 & 0.079 & 4.17 & 3.22 & 7.15 & 3.71 \\
\hline \multicolumn{12}{|c|}{ Irrigation regimes } \\
\hline $\mathrm{I}_{1}$ (Control) & 0.046 & 0.049 & $3.76 \mathrm{~A}$ & & $3.92 \mathrm{~A}$ & $7.88 \mathrm{~B}$ & $7.96 \mathrm{~A}$ & $43.94 \mathrm{~A}$ & $42.91 \mathrm{~A}$ & $113.14 \mathrm{~A}$ & $54.00 \mathrm{~A}$ \\
\hline $\mathrm{I}_{2}(\mathrm{PRD})$ & 0.044 & 0.047 & $3.18 \mathrm{~B}$ & & $3.61 \mathrm{~B}$ & $8.17 \mathrm{~A}$ & $8.23 \mathrm{~B}$ & $30.75 \mathrm{~B}$ & $28.33 \mathrm{~B}$ & $44.17 \mathrm{~B}$ & $34.75 B$ \\
\hline LSD & NS & NS & 0.14 & & 0.03 & 0.16 & 0.18 & 2.04 & 2.35 & 1.13 & 3.77 \\
\hline \multicolumn{12}{|c|}{ Ground covers $\times$ Irrigation } \\
\hline $\mathrm{M}_{0} \mathrm{I}_{1}$ & 0.04 & 0.043 & 3.68 & 3.85 & $7.82 \mathrm{~d}$ & 7.86 & 78 & & $77.33 \mathrm{a}$ & $219.57 \mathrm{a}$ & $86.66 \mathrm{a}$ \\
\hline $\mathrm{M}_{0} \mathrm{I}_{2}$ & 0.04 & 0.046 & 3.07 & 3.44 & $8.04 \mathrm{c}$ & 8.08 & 49 & & $47.00 \mathrm{~b}$ & $49.67 \mathrm{de}$ & $48.33 c$ \\
\hline $\mathrm{M}_{1} \mathrm{I}_{1}$ & 0.05 & 0.05 & 3.86 & 4.09 & $7.98 \mathrm{c}$ & 8.06 & 20 & & $20.33 \mathrm{e}$ & $58.33 d$ & $24.66 \mathrm{f}$ \\
\hline $\mathrm{M}_{1} \mathrm{I}_{2}$ & 0.05 & 0.054 & 3.31 & 3.83 & $8.29 \mathrm{a}$ & 8.35 & 13 & & $11.00 \mathrm{f}$ & $24.00 \mathrm{f}$ & $17.66 \mathrm{~g}$ \\
\hline $\mathrm{M}_{2} \mathrm{I}_{1}$ & 0.04 & 0.043 & 3.78 & 3.89 & $7.87 \mathrm{~d}$ & 8.01 & 33 & & $32.66 \mathrm{~d}$ & $79.67 \mathrm{c}$ & $42.66 \mathrm{~d}$ \\
\hline $\mathrm{M}_{2} \mathrm{I}_{2}$ & 0.05 & 0.051 & 3.23 & 3.64 & $8.20 \mathrm{ab}$ & 8.31 & 26 & & $24.00 \mathrm{e}$ & $44.33 \mathrm{e}$ & $32.00 \mathrm{e}$ \\
\hline $\mathrm{M}_{3} \mathrm{I}_{1}$ & 0.04 & 0.042 & 3.73 & 3.84 & $7.86 \mathrm{~d}$ & 7.91 & 43 & & $41.33 c$ & $95.00 \mathrm{~b}$ & $62.00 \mathrm{~b}$ \\
\hline $\mathrm{M}_{3} \mathrm{I}_{2}$ & 0.05 & 0.047 & 3.11 & 3.54 & $8.15 b$ & 8.20 & 33 & & $31.33 \mathrm{~d}$ & $58.67 d$ & $41.00 \mathrm{~d}$ \\
\hline LSD & NS & NS & NS & NS & NS & NS & & & 4.56 & 10.11 & 5.25 \\
\hline
\end{tabular}

Means not sharing a common letter differ at $5 \%$ probability level. 


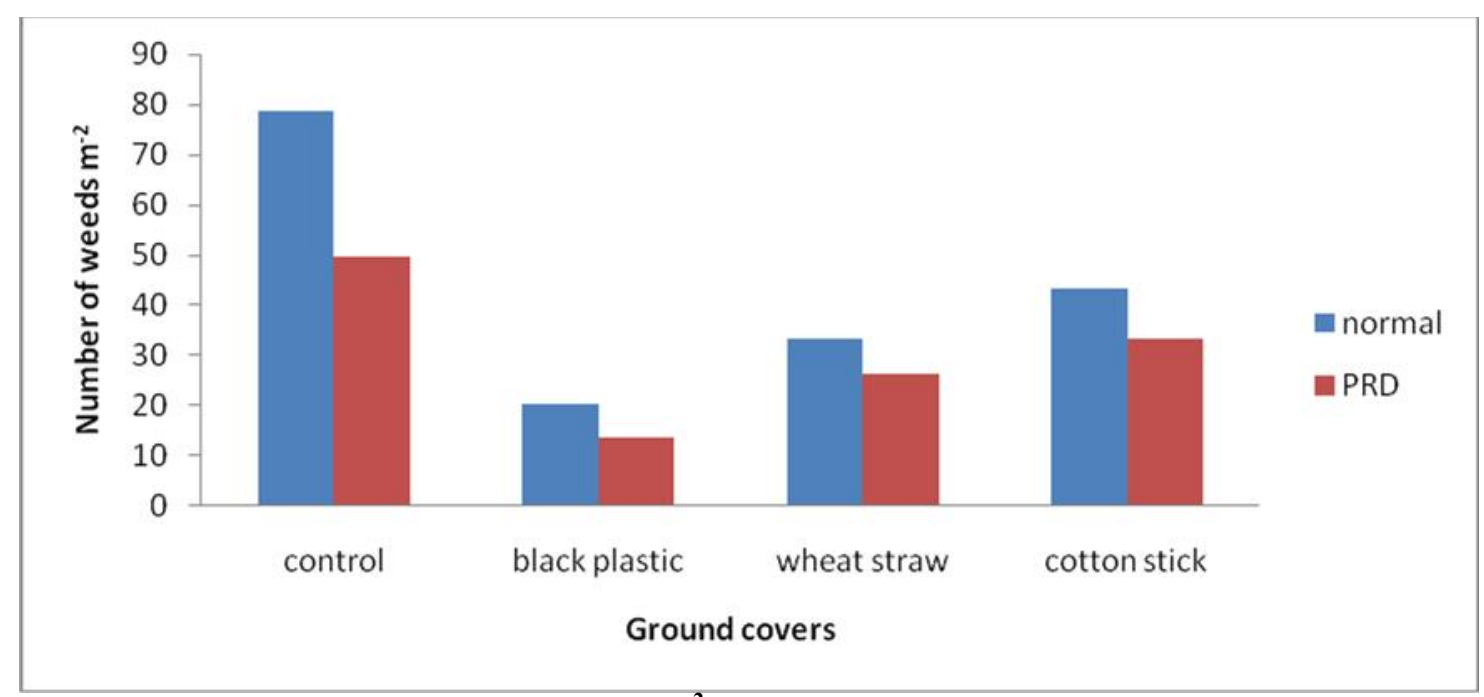

Fig.1. Effect of ground covers on number of weeds $\mathrm{m}^{-2}$ in wheat under different irrigation regimes

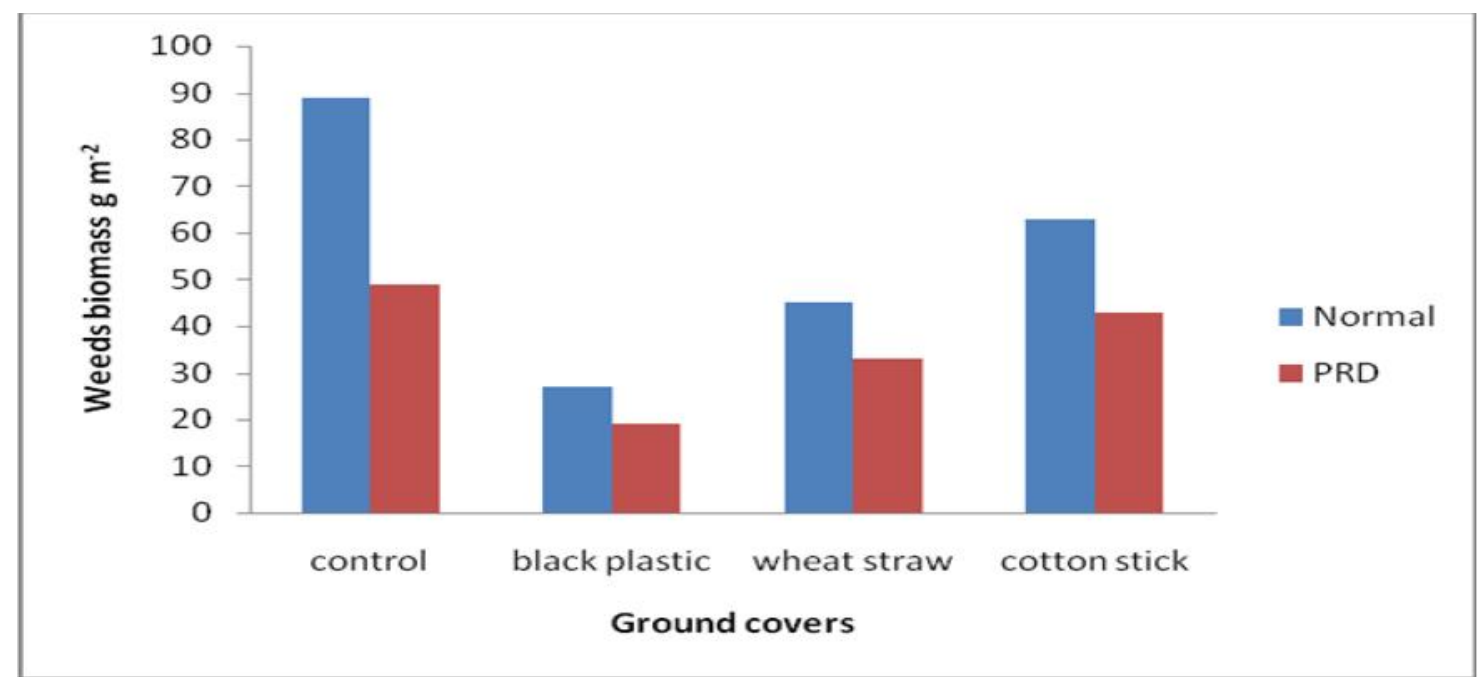

Fig.2. Effect of ground covers on weed biomass in wheat under different irrigation regimes.

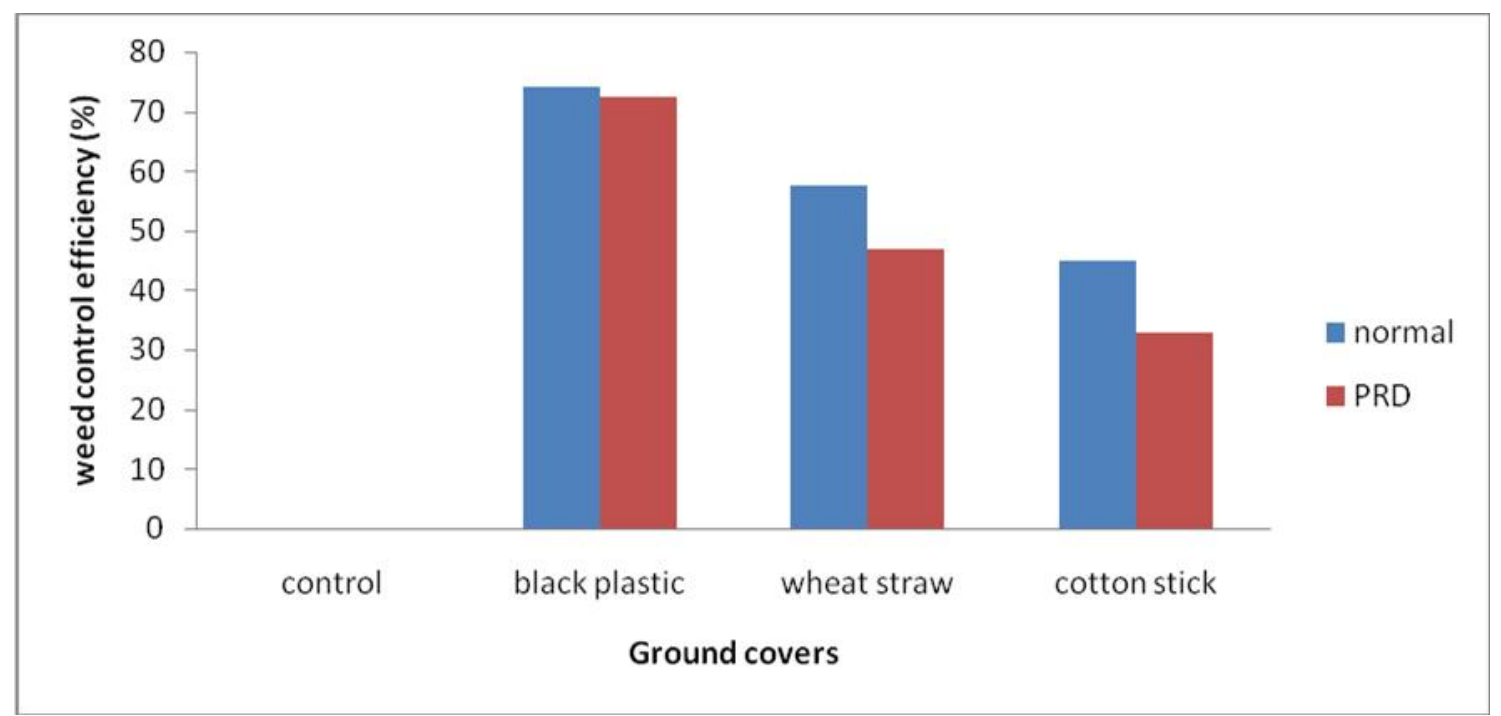

Fig.3.Effect of ground covers on weed control efficiency in wheat under different irrigation regimes 
Conclusion: Wheat yield attributes were more in normal irrigation treatment while grain NPK contents and water use efficiency were more in PRD treatment. All ground covers markedly improved the wheat yield attributes and quality contents as well as efficiently controlled the weeds as compared to open (uncover) ground conditions. Combined use of PRD with black plastic cover gave best results than other combinations used in the experiment.

Acknowledgements: The research grant from Higher Education Commission Pakistan for successful conductance and execution of research trial under project \# 20-4968/NRPU/ R\&D/HEC is highly acknowledged.

\section{REFERENCES}

Ahmad, S., M.A.S. Raza, M.F. Saleem, S.S. Zahra, I.H. Khan, M. Ali, A.M. Shahid, R. Iqbal and M.S. Zaheer. (2015). Mulching strategies for weeds control and water conservation in cotton. $\mathrm{J}$. Agric. Biol. Sci. 8, 299-306.

Bandopadhyay, S., L.Martin-Closas, A.M. Pelacho, and J.M.DeBruyn. (2018). Biodegradable plastic mulch films: Impacts on soil microbial communities and ecosystem functions. Front. Microbial. 9, 8-19.

Battaglia, B.C., C. Datel, C. Dejac, G. Gambaretto, G.B. Guarise, G. Perin, E. Vianello and F. Zingales. (1983). Hydrothermo dynamic and biological investigations to determine the environmental consequences of the functionality at full working-order of the enelthermoelectric plantinportomarghera (initalian). 4. regioneveneto,venezia.

Blum, A. (2017). Osmotic adjustment is a prime drought stress adaptive enginein support of plant production. Plant, Cell Environ. 40(1), 4-10.

DelaHera, M.L., P. Romero, E. Gomez-Plaza, and A. Martinez. (2007). Is partial root-zone drying an effective irrigation technique to improve water use efficiency and fruit quality in field-grown wine grapes under semi arid conditions? Agric. Water Manag. 87(3), 261-274.

Merwe,V., and J.D. Prins. (2012). The effects of organic and inorganic mulches on the yield and fruit quality of Cripps'Pink'apple trees (Doctoral dissertation, Stellenbosch: Stellenbosch University).

Dwivedi, S.K., A. Arora, V.P. Singh, and G.P.Singh. (2017). Induction of water deficit tolerance in wheat due to exogenous application of plant growth regulators: membrane stability, water relations and photosynthesis. Photosynthetica, 19.

Farooq, M., A. Wahid, N. Kobayashi, D. Fujita, and S.M.A. Basra. (2009). Plant drought stress: effects, mechanisms and management. In sustainable agriculture (pp. 153-188). Springer Netherlands.

Fereres, E, and M. García-Vila. (2019). Irrigation Management for Efficient Crop Production. Crop Science, 345-360.

Gaba,S., E. Gabriel, J. Chadœuf, F. Bonneu, and V. Bretagnolle. (2016). Herbicides do not ensure for higher wheat yield, but eliminate rare plant species. Sci. Reports, 6, 301-312.

Game,V.N., S.A. Chavan, U.V. Mahadkar, R.T. Thokal, andG.B. Shendage. (2017). Response of rabi sweet corn (Zea mays saccharata L.) to irrigation and mulching in Konkan Region of Maharashtra. J. Indian Soc. Coastal Agric. Res, 35(1), 27-30.

Grimes, D.W., V.T. Walhood, and W.L. Dickens. (1968). Alternate-furrow irrigation for San-Joaquin valley cotton. California Agri., 22, 4-6.

Harker,K.N., and J.T. O'donovan. (2013). Recent weed control, weed management, and integrated weed management. Weed Technol. 27(1), 1-11.

Hassan, M.U., M. Aamer, M.U. Chattha, M.A. Ullah, S. Sulaman, M. Nawaz, and H. Guoqin. (2017). The role of potassium in plants under drought stress: Mini Review. J. Basic Appl. Sci. 13, 268271.

Hussain, G., and A.A. Al-Jaloud. (1995). Effect of irrigation and nitrogen on water use efficiency of wheat in Saudi Arabia. Agric. Water Manag. 27(2), 143-153.

Hussain, S., A. Khaliq, A.A. Bajwa, A. Matloob, A. Areeb, U. Ashraf, and M.Imran. (2017). Crop growth and yield losses in wheat due to little seed canary grass infestation differ with weed densities and changes in environment. Planta Daninha, 35.

Hutton, R.J., and B.R. Loveys. (2011). A partial root zone drying irrigation strategy for citruseffects on water use efficiency and fruit characteristics. Agric. Water Manag. 98(10), 1485-1496.

Ijaz, S.S., and S. Ali. (2007). Tillage and mulch effects on profile moisture dynamics fallow efficiency and rainfed wheat yields in Potowar. Pakistan J. Agri. Sci. 44, 90-95.

Kirda, C., M. Cetin, Y. Dasgan, S. Topcu, H. Kaman, B. Ekici, and A.I. Ozguven. (2004). Yield response of green house grown tomato to partial root drying and conventional deficit irrigation. Agric. Water Manag. 69(3), 191-201.

Kumari, A. (2012). Physiological and molecular constraints limiting grain growth under water stress in wheat genotypes (doctoral dissertation, IARI, division of plant physiology). 
Kusakabe, A., B.A. Contreras-Barragan, C.R. Simpson, J.M. Enciso, S.D. Nelson, and J.C. Melgar. (2016). Application of partial root zone drying to improve irrigation water use efficiency in grape fruit trees. Agric. Water Manag.178, 6675.

Manikavelu, A., K. Kawaura, H. Imamura, M. Mori, and Y. Ogihara. (2011). Molecular mapping of quantitative trait loci for domestication traits and $\beta$-glucan content in a wheat recombinant inbred line population. Euphytica, 177(2), 179-190.

Maqbool, M.M., A. Ali, T. Haq, M.N. Majeed, and D.J. Lee. (2015). Response of spring wheat (Triticum aestivum L.) to induced water stress at critical growth stages. Sarhad J. Agric., 31(1), 53-58.

Maurya, A.C., S.K. Verma, S. Kumar, and K. Lakra. (2017). Nutrient concentration and their uptake and available nutrients in soil influenced by irrigation, mulching and integrated nutrient management in summer groundnut. Int. J. Current Microbiol. Appl. Sci. 6(11), 2405-2415.

Mummey, D.L., J.L. Smith, and J.H. Bolton. (1994). Nitrous oxide flux from a shrub-steppe ecosystem: sources and regulation. Soil Biol. Biochem. 26(2), 279-286.

Mwadzingen, L., H. Shimelis, E. Dube, M.D. Laing, and T.J. Tsilo. (2016). Breeding wheat for drought tolerance: Progress and technologies. J. Integ. Agric., 15(5), 935-943.

Nasrullah, M., M.B. Khan, R. Ahmad, S. Ahmad, M. Hanif, and W. Nazeer, (2011). Sustainable cotton production and water economy through different planting methods and mulching techniques. Pakistan J. Bot. 43 (4), 1971-1983.

Othieno, C.O. (1973). The effect of organic mulches on yields and phosphorus utilization by plants in acid soils. Plant Soil, 38(1), 17-32.

Ramakrishna, A., H.M. Tam, S.P. Wani, and T.D. Long. (2006). Effect of mulch on soil temperature, moisture, weed infestation and yield of ground nutin Northern Vietnam. Field Crops Res., 95 (2-3), 115-125.
Raza, M. A. S., S. Ahmad, M. F. Saleem, I. H. Khan, R. Iqbal, M. S. Zaheer, and M. Ali. (2017). Physiological and biochemical assisted screening of wheat varieties under partial rhizosphere drying. Plant Physiol. Biochem., 116: 150-166.

Saeed, H., I.G. Grove, P.S. Kettlewell, and N.W. Hall. (2008). Potential of partial root zone drying as an alternative irrigation technique for potatoes (Solanum tuberosum). Ann. Appl. Biol. 152(1), 71-80.

Sekhon, N.K., C.B. Singh, A.S. Sidhu, S.S. Thind, G.S. Hira, and D.S. Khurana. (2008). Effect of straw mulching, irrigation and fertilizer nitrogen levels on soil hydrothermal regime, water use and yield of hybrid chilli. Arch. Agron. Soil Sci. 54(2), 163-174.

Shahid, M., M.F. Saleem, S.A. Anjum, M. Shahid, and I. Afzal. (2017). Biochemical markers assisted screening of Pakistani wheat (Triticum aestivum L.) cultivars for terminal heat stress tolerance. Pakistan J. Agric. Sci. 54(4), 837-845.

Shahnazari, A., F. Liu, M.N. Andersen, S.E. Jacobsen, and C.R. Jensen. (2007). Effects of partial rootzone drying on yield, tuber size and water use efficiency in potato under field conditions. Field Crops Res., 100(1), 117-124.

Steel, Steel R.G.D., J.H. Torrie, and D.A. Dickey. (1997). Principles and procedure of statistics. McGrow Hill book Co., US, pp: 178-182.

Taheri, S., J. Saba, F. Shekari, and T. Abdullah. (2011). Effects of drought stress condition on the yield of spring wheat (Triticum aestivum) lines. Afr. J. Biotechnol., 10, 18339-18348.

Tester, M., and P. Langridge. (2010). Breeding technologies to increase crop production in a changing world. Sci., 327, 818-822.

Tilman, D., C. Balzer, J. Hill, and B.L. Befort. (2011). Global food demand and the sustainable intensification of agriculture. Proceedings of the National Academy of Sciences, 108(50), 2026020264. 